\title{
Impact of Selected Environmental Pollutants on the Ultrastructure of the Gills in Pinctada radiata from Coastal Zones, Egypt
}

\author{
Sherifa Shaker Hamed1,2, Eman Hashem Radwan ${ }^{3 *}$, Gaber Ahmed Saad ${ }^{4,2}$ \\ ${ }^{1}$ Department of Zoology, College of Science, King Saud University, Saudi Arabia, KSA \\ ${ }^{2}$ Department of Zoology, Faculty of Science, Alexandria University, Alexandria, Egypt \\ ${ }^{3}$ Department of Zoology, Faculty of Science, Damnhour University, El Behara, Egypt \\ ${ }^{4}$ Department of Biology, College of Medicine, Dammam University, Saudi Arabia, KSA \\ Email: ${ }^{*}$ Dr eman hashem@yahoo.com
}

Received 29 June 2014; revised 29 July 2014; accepted 10 August 2014

Copyright (C) 2014 by authors and Scientific Research Publishing Inc.

This work is licensed under the Creative Commons Attribution International License (CC BY). http://creativecommons.org/licenses/by/4.0/

(c) (i) Open Access

\section{Abstract}

There has been an increasing interest in marine oysters (order: Petridae) in recent years because their numbers are declining in many parts of the world and also because they are used as monitors of pollution. The present study describes the microscopic structure of gills as viewed by light and electron microscopy in two locations selected in Alexandria coast, Eastern Harbor (E.H.) and El Asafra. The specimens in the E.H. represent the presence of extracellular mineralized granules.

\section{Keywords}

\section{Gill, Bivalve, Transmission Electron Microscope, Pinctada radiata}

\section{Introduction}

There are over 6500 species of marine bivalves in the phylum Mollusca [1], including oysters. Marine bivalves are known to be natural unique accumulators of contaminants [2]. The environment had become increasingly aware of the importance environmental risk management in the economic development, health and quality of life [3]. [4] and [5] reported that Pinctada radiata could be used as indicator species for heavy metals accumulation studies. The sensitive aquatic environment is suffering of pollution that affects both quantity and quality of ${ }^{*}$ Corresponding author.

How to cite this paper: Hamed, S.S., Radwan, E.H. and Saad, G.A. (2014) Impact of Selected Environmental Pollutants on the Ultrastructure of the Gills in Pinctada radiata from Coastal Zones, Egypt. Open Journal of Ecology, 4, $907-917$. 
benthic invertebrate biodiversity [6].

Bivalves are used in monitoring programmes in the marine environment due to their ability to concentrate pollutants to several orders of magnitude above ambient levels in seawater [7]-[9]. [10] and [11] reported that bivalves had been used as successful biomonitors of aquatic metallic pollutant levels internationally prominent examples including the United States National Oceanic and Atmospheric Administration Mussel Watch Programmes and the Australian Oyster Watch Programmes. Cadmium levels in hepatopancreas were lower than those in gills [12]. Shellfish plays an important role in the ecology of aquatic pathogens [13], and [14]. Histopathology is a tool for monitoring anthropogenic contamination [15] [16].

\section{Materials and Methods}

\subsection{Sampling}

\subsubsection{Water Samples}

Coastal water samples were collected from the three selected locations on the coast of the Alexandria at $3-5 \mathrm{~m}$ depth for the determination of copper, and cadmium. Seawater samples were filtered through $0.45 \mu \mathrm{m}$ millipore filters to remove any debris particles then stored at $-20^{\circ} \mathrm{C}$ until analysis. All concentrations are reported as $\mu \mathrm{g} / \mathrm{l}$ for seawater. All the precautions recommended by [17] to minimize risks of sample contamination were followed during collection and treatment of samples.

\subsubsection{Mollusk Samples}

The Bivalve were collected in sterile plastic bag (no. 250/location/season, replicant, 5 time) and were cleaned from attached organisms and then rinsed with seawater from their sampling locations and transported to the laboratory within 4 - 6 hrs.

\subsubsection{Analytical Methods}

\section{1) Heavy metals in seawater}

The concentration of heavy metals were determined in the collected seawater samples using Graphite Furnace Atomic Absorption Spectroscopy (Perkin-Elmer model 2380) under the recommended conditions and the detection limits in the manual for each metal [18].

\section{2) Physicochemical analysis of seawater}

Surface water samples were collected five times; bi-week from three sites representing the coastal area in front of Alexandria city at each location, water samples were collected using polyethylene bottles (2-liters capacity). The polyethylene bottles were previously cleaned with detergent rinsed several times with distilled water, soaked in 1 N HCL for several days and finally rinsed with re-distilled water. At each site a $150 \mathrm{ml}$ dissolved oxygen bottle was firstly filled and immediately fixed, using manganous sulphate and alkaline potassium iodide solution [19]. Some parameters were totally or partially measured in the field i.e. as soon as the sample was collected. These steps of the methods would be explained by the term "in situ" in the text. Temperature measurements: In situ at each station, air and water temperatures were measured at the time of water sampling using an ordinary thermometer. Salinity (S\%): Salinity was determined by measuring the electrical conductivity using an inductive Salinometer (Beckman; model RS. 10). Hydrogen-ion concentration [pH]: The $\mathrm{pH}$-value of water sample was measured in the laboratory immediately after collection using Bench type (JENWAY, 3410 Electrochemistry Analyzer pH-meter). Dissolved oxygen (BOD: It was determined by a modified Winkler's method [20].

\section{3) Heavy metals in tissue}

The preparation of samples to determine concentration of heavy metals was carried out animals were separated from the shells; weighed and digested using conc. $\mathrm{HNO}_{3}$ in Taflon digestion vessels. Wet digested samples were diluted with deionized distilled water and analyzed by Ion-selective electrod AVL. The obtained data were expressed as $\mu \mathrm{g} / \mathrm{g}$ wet weight [21]. The analytical method was checked by (5 replicate) measurements for the studied metals in a sample of marine.

\section{4) Histological studies on gills of (Bivalve, Mollusca)}

a) Light microscopical technique: In order to establish the histological state, twenty individuals from each sampling site/month, were processed for light microscopical study [22]. The shells were removed gently then the soft specimen was quickly dissected. 
b) Electron microscopy: Specimens were fixed in 2.5\% glutaraldehyde solution ( $\mathrm{pH} 7.2$, buffered $0.1 \mathrm{M}$ phosphate buffer) for $2-4$ hrs at $4^{\circ} \mathrm{C}$ and rinsed in $0.1 \mathrm{M}$ phosphate buffer and then post-fixed in $1 \%$ osmium tetroxide $\left(\mathrm{OsO}_{4}\right)$ solution for $2 \mathrm{hrs}$ at $4^{\circ} \mathrm{C}$. After fixation, the specimens were washed with $0.1 \mathrm{M}$ phosphate buffer 4 times for 2 hrs and dehydrated with ascending grades of ethanol. Specimens for transmission electron microscope (TEM) were embedded in Epon 812, cut at ultrathin sections (70 nm in thickness) and placed on copper grids (200 mesh) in order to double-stain with uranyl acetate and lead citrate. Specimens were examined using a TEM (JEM-1200EXII, JEOL, Japan).

Semithin sections $(0.5-1.0 \mu \mathrm{m})$ were cut using LK Bill ultra-microtome. In order to stain the resin embedded sections, they were rinsed for 1 - 2 minutes in about $1 \%$ toluidine blue solution in $1 \%$ borax. They were then washed in tap water, dried on hot plate (60C) and mounted in Canada balsam. Toluidin blue-stained sections were examined and photographed using Diallux 20EB Leitz research microscope provided with Canon camera. Ultrathin sections were cut from the resin blocks at a thickness of $10 \mathrm{~nm}$ using glass or diamond knives. Sections were mounted on coated grids (1\% partodion in amyl acetate) and stained in solution of aqueus or alcoholic uranyl acetate for about 15 - 20 minutes. After drying, they were examined.

\subsection{Statistical Analysis}

Statistical analysis was performed using two-way ANOVA using SPSS computer program (version 14.0) to check for significant difference between metal concentrations in different localities.

\section{Results}

The ecological investigations of water were restricted to two locations; El Asafra and the Eastern Harbor (E.H.). All parameters were measured monthly and they are shown in Figure 1(a), Figure 1(b).

The gills consists of two plates at each side of animal, the gill plate is comprised of parallel filaments, connected by cillialry discs. Each gill filament is divided into abfrontal, intermediates and frontal zone (Figure 2(a), Figure 2(b)). In the center of the filaments, haemocytes circulate through the haemolymph vessel. The frontal surface of a gill filament bears frontal cilia, latero frontal and lateral cilia (Figure 3(a), Figure 3(b)). The wall of the gill filament is lined with ciliated columnar epithelial cells with ovoid nuclei, between them there are a number of mucous secretory cells with circular nuclei.

Three types of cells had been reported by transmission electron micrographs. Cells containing several large mitochondria, flattened epithelial cells covered the first type and with elongated microvilli, mucous cells enclosed between the first one. There were no obvious surface morphological abnormalities of gill filament in animals collected from E.H. or El Asafra. Little increase in the mucous secretion and lateral cilia increased in length and number in oyster gill collected from the E.H. (Figure 4(a), Figure 4(b)).

The histo pathological changes directed to the arrangement of regularity of gill lamellae and occasional areas avoid of microvilli appeared on some frontal and lateral surfaces. Black granules were detected throughout the cells and in some cases the mitochondrial membrane started to decay. There were some areas where abfrontal surface were lacking of cilia, in some cases frontal and abfrontal cells appear necrotic, their internal organelles getting out into the extracellular space.

There were some alteration in filaments morphology with increase in vacuoles and decrease in mitochondria number which sometimes completely disappeared and several gill filaments were dilated. In the present study, histology showed haemocyte infiltration (Figure 6).

In Electron microscopic sections, the central zone of the gills, consists of a sheet of tissue with outer and inner epithelia separated by loose interstitial tissue containing haemolymph spaces, haemocytes, muscles and variable numbers of large vesicular cells (Figures 2-4). In the central zone of the gills of Pinctada radiata, there were generally loosely packed vesicular cells and large extracellular spaces, often traversed by thin muscle fibers. In some specie men the interstitial tissue was with numerous clusters of granules among the vesicular cells. In some specimens, the tissue was much denser, as shown in (Figure 5(a), Figure 5(b) and Figure 6(b)). Larger granules were also often found scattered through the tissue.

The vesicular cells (Figure 5(a) and Figure 6(a)) were large, with a central region filled with fine granular storage material and a thin peripheral layer of cytoplasm containing the nucleus. Muscle cells contained thin filaments and dense bodies, with no cross striations. Mitochondria lay peripherally, often in large lateral cytoplasmic projections. Lateral projections often contained large amounts of granular material. Muscle cells varied in 


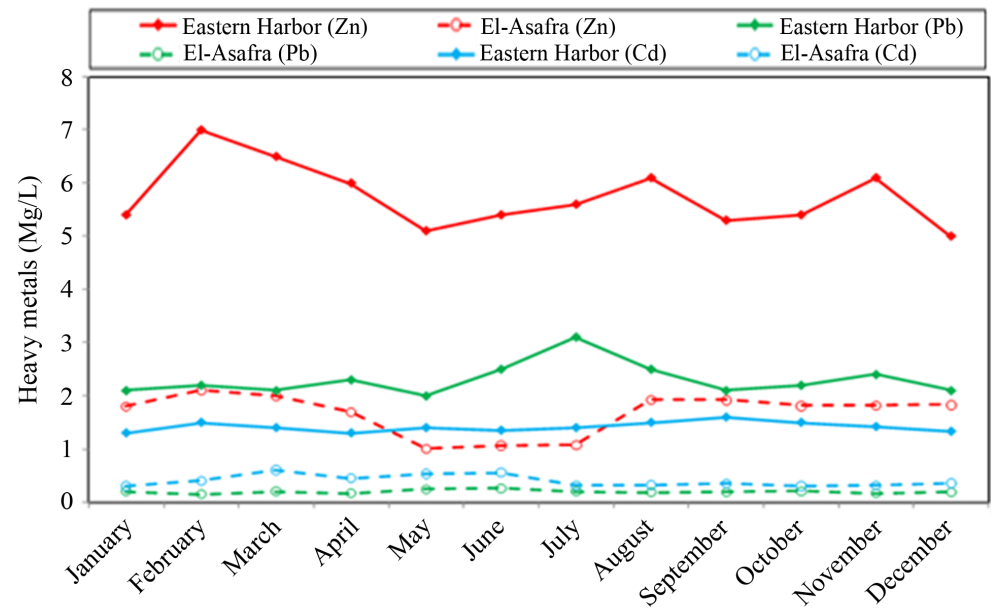

(a)

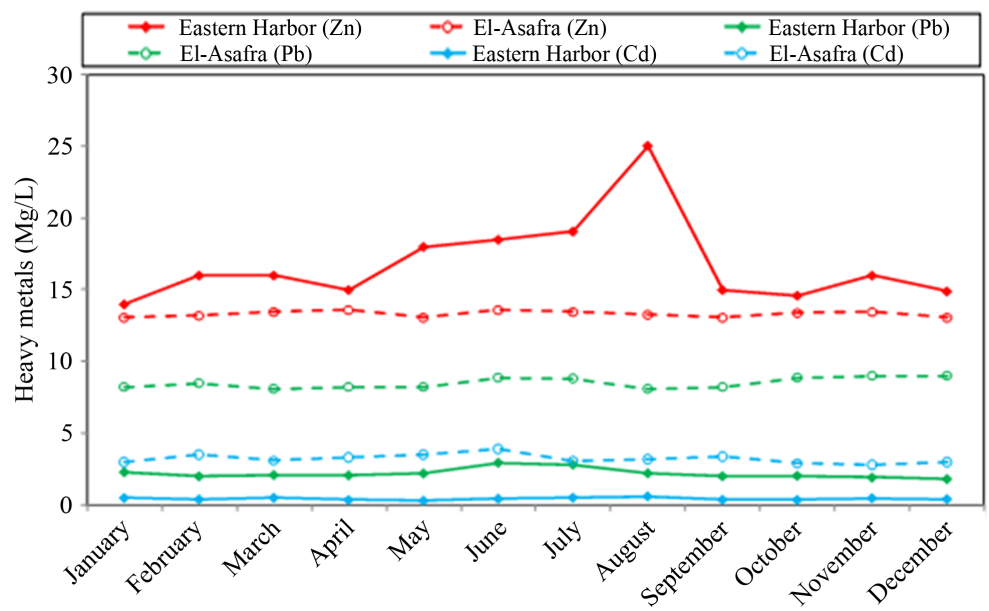

(b)

Figure 1. (a) Comparison between E.H. and El Asafra in the sea sample according to heavy metals. (b) Comparison between Eastern Harbor and El Asafra in gills of Pinctada radiata ( $\mu \mathrm{g} / \mathrm{g}$ ) according to heavy metals.

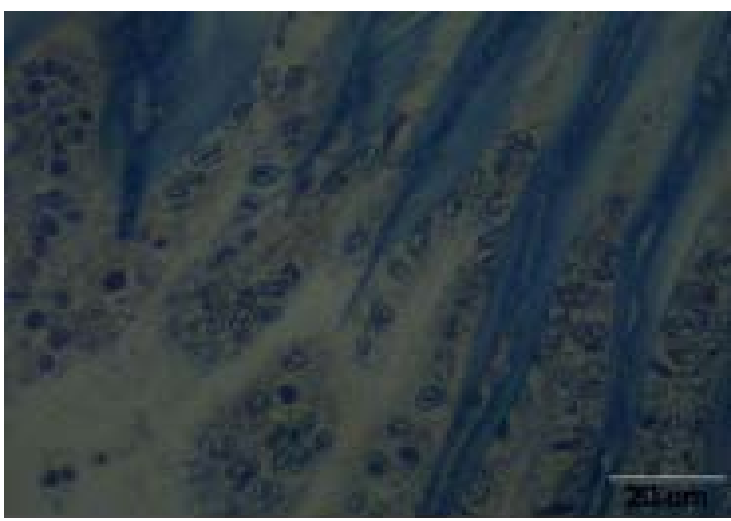

(a)

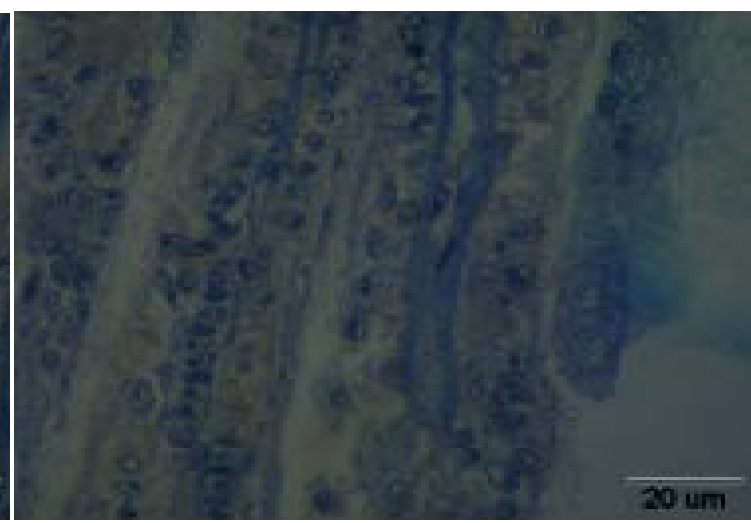

(b)

Figure 2. Photomicrograph, semithin, of gill of Pinctada radiata, collected from El Asafra showing gill filaments (G.F.), inter filamentary junction (IFJ), frontal (FS) and lateral (LS) and inter lateral surfaces (ILs) of gill filaments. 


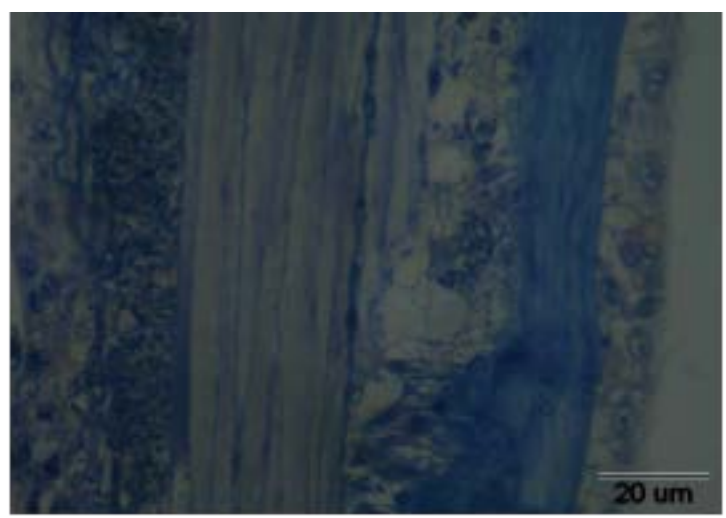

(a)

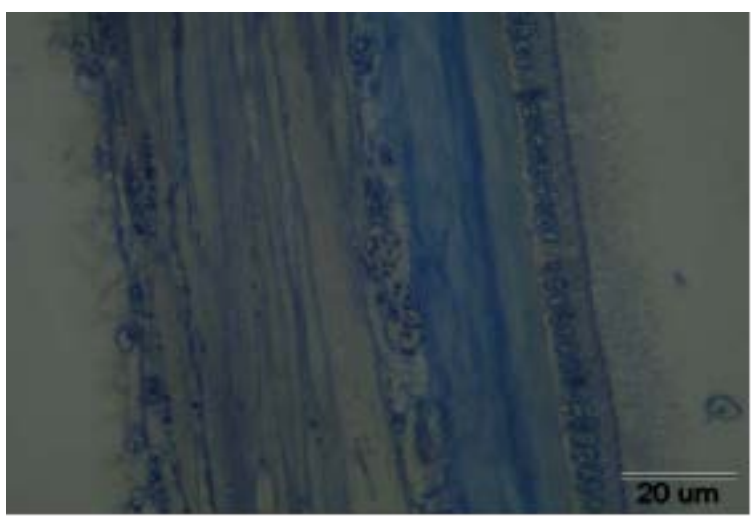

(b)

Figure 3. Photomicrograph, semithin, of gill of Pinctada radiata collected from El Asafra showing; mucocytes (Mu), frontalsurface (FS), haemocoel (H), lateral cilia (LFC), lateral cilia (LC), mucocyte (Mu) and nucleus (N).

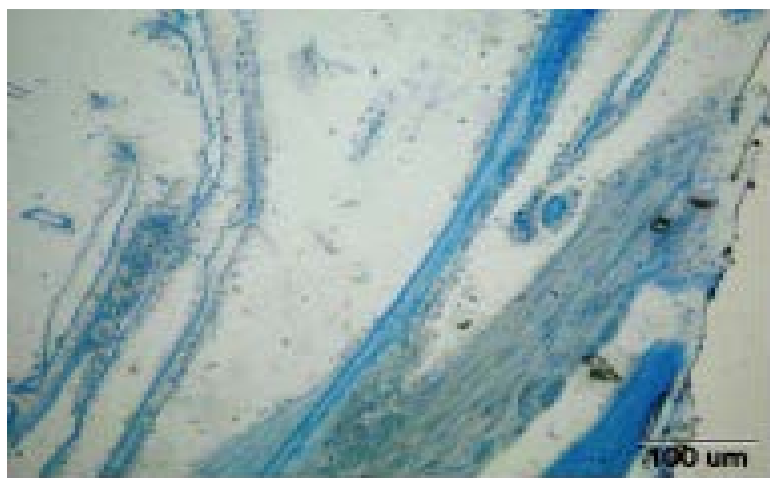

(a)

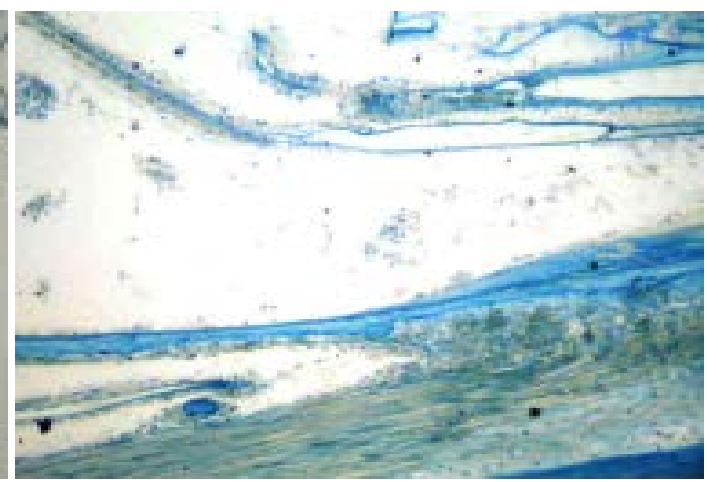

(b)

Figure 4. Photomicrograph, semithin, of Pinctada radiata collected from E.H. showing abnormal gill showing abnormal shape and irregular arrangement of gill filaments (G.F.), haemocoel (H.) and decay of frontal surface.

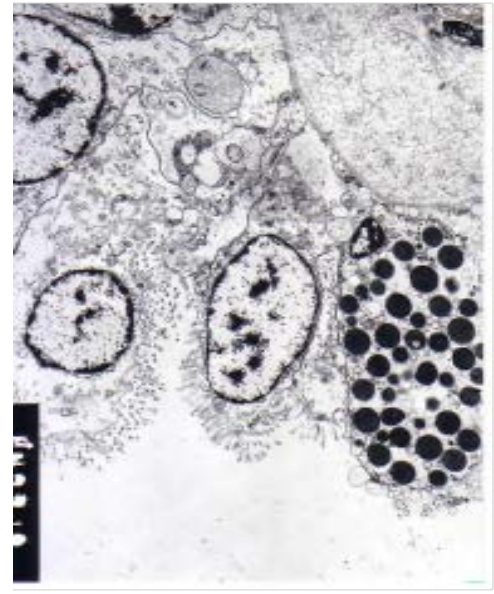

(a)

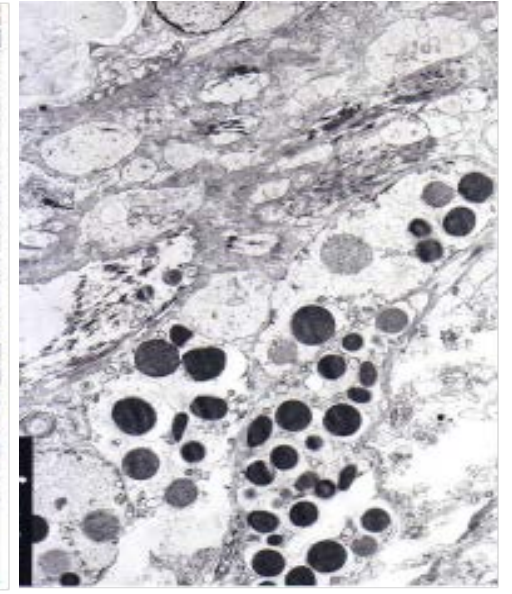

(b)

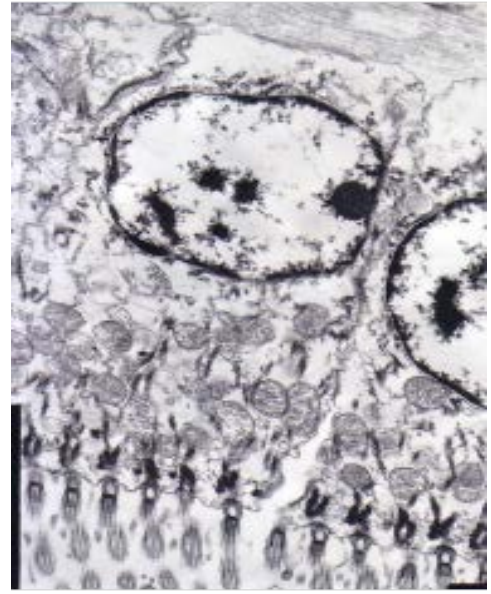

(c)

Figure 5. (a) (b) TEM micrograph of normal gill filament in the frontal zone of gill filament of oyster collected from El Asafra, showing the thin cells with microvilli (MV) cover the apical surface of cells. (c) TEM micrograph of normal gill filament from El Asafra showing the mucous cell (Mu), cells with many mitochondria (M) and nucleus (N).

size, from large thick cells in the muscle bands traversing the distal margin of the gills, to thin fibers laying under the epithelia (Figures 7(a)-(c)). 


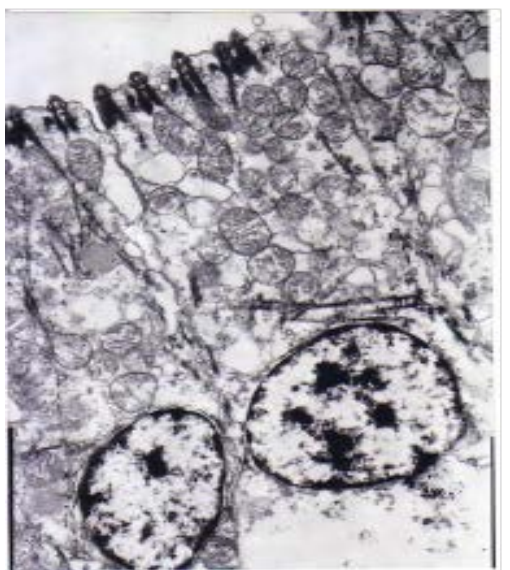

(a)

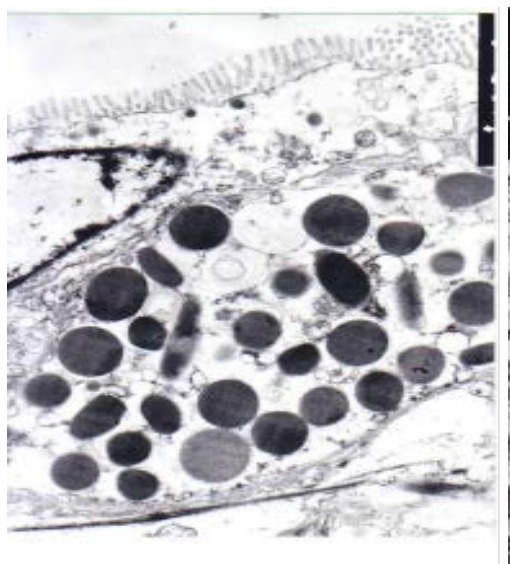

(b)

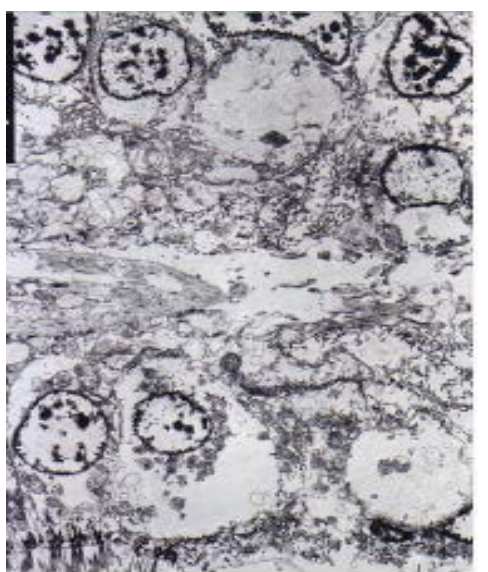

(c)

Figure 6. (a) (b) TEM micrograph of normal gill filament in the frontal zone of gill filament of oyster collected from El Asafra, showing the thin cells with microvilli (MV) cover the apical surface of cells. (c) TEM micrograph of normal gill filament from El Asafra showing the mucous cell (Mu), cells with many mitochondria (M) and nucleus (N).

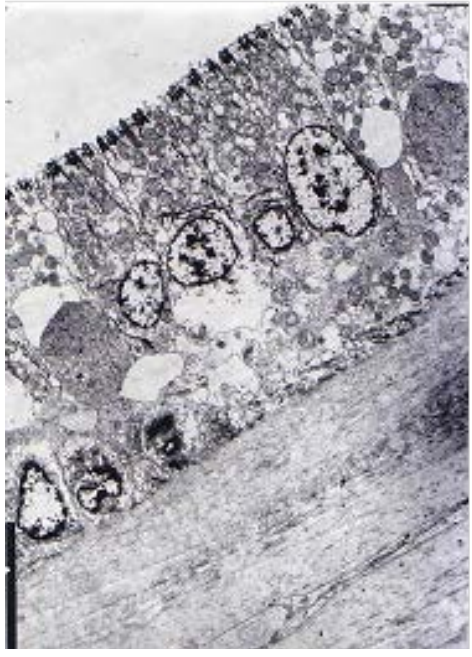

(a)

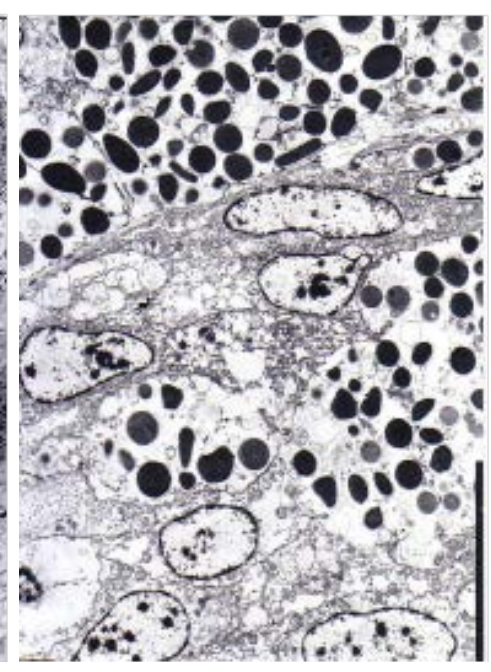

(b)

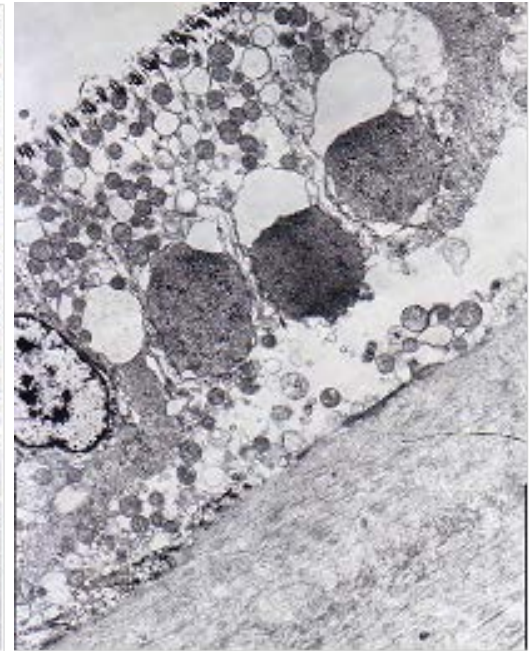

(c)

Figure 7. (a) (b) (c) TEM micrograph of gill illustrating the decayed mitochondria (M) and mitochondrial memberane; gill oyster collected from E.H.

The most common type of haemocyte observed in the oysters was a large granulocyte with vesicles containing amorphous material (granules), in descriptions of haemocytes because of their granular appearance by light microscopy. There were also smaller numbers of haemocytes without large vesicles. These had variable nucleus, cytoplasm ratios and variable numbers. Gills contained varying quantities of granules. Most granules were extracellular, Granules were also scattered in the interstitial tissue. In some specimens, granules were generally very numerous, the majority of granules occurred as large clusters of small granules.

\section{Discussion}

Sea food is considered as an important source of protein for human [23]. In the present study the concentration of heavy metals is considered less than that reported by [24]. It is concluded that the coastal area in Mediterranean sea of Egypt might be considered relatively unpolluted with heavy metals. [25] reported that the coastal area in Mediterranean sea of Egypt might be considered relatively unpolluted with heavy metals. In all cases the average concentrations of trace elements in Egyptian Mediterranean coast are far from the hazardous concentrations [26]. They revealed that the origin of trace elements in the sampled water of the Egyptian Mediterranean 
was mainly the waste water discharge. [27] reported that the uptake of metals may take place at the gills of bivalve. Only gills of bivalves can be considered as an adequate target tissue for heavy metals [28]. [29] suggested that the gill in Mussel Mytilus edulis appeared to be more suitable organ for biomonitoring heavy metals. Bivalves are frequently used in marine ecotoxicology for the purpose of assessing seawater quality because they are very sensitive to pollutants [30]. Gills are frequent targets of environmental pollutants because they are the main interface between the organisms and their environment [31]. Gills are the target organ in oysters exposed to high concentrations of heavy metals [32].

Histopathological alterations of gills of bivalve tissues have been shown to be responsive and sensitive to wide range of contaminants because they play an important role in respiration and food collection [33]-[35]. The histopathological changes of gills of bivalve in the present study are in agreement with [2] and [36] as they reported irregularity of gill lamellae of the cells, swelling of gill filaments and haemocytes infiltration of bivalve. Epithelial cells of the gills play a crucial role [37]; the damage in the epithelium results in serious dysfunction of tissues consequently leading to deleterious effect on the organization levels [2]. Bivalves possess different measures of defense against environmental hazards e.g. particle rejection and formation of pseudo faces, reduced filtration rate and valve closure [38]. Haemocytes in bivalves possess a variety of functions, including regeneration, digestion and phagocytosis of foreign particles and pathogens [39]. The major environmental problem in the coastal area is directly related to the impact of domestic effluents [40].

[41] reported that metal concentrations recorded in the soft tissues of mussels Mytilus galloprovincialis increased without a source of extra metals in water. [26] revealed that the origin of trace elements in the sampled water of the Egyptian Mediterranean was mainly the waste water discharge. They added that the surface east water current and south west winds blowing on the Mediterranean coast of Egypt contributed mostly in spreading the trace elements to wide areas of the coast. [28] found that the degree of environmental contamination was only one among several factors that influenced metal concentrations in animals. Bioavailability or specific sources may be responsible for higher concentrations in apparently less impacted environments. [29] suggested that gills of bivalves appeared to be a more suitable organ for biomonitoring than that of the hepatopancreas. Bivalves are frequently used in marine ecotoxicology for the purpose of assessing seawater quality because they are very sensitive to pollutants [30]. Gills are frequent targets of environmental pollutants because they are the main interface between the organisms and their environment [31] and [32].

Mediterranean is surrounded by 18 countries from three continents (Europe, Africa and Asia) [42]; intense human activities from these countries produce a strong environmental impact in form of marine degradation [43], and cause heavy metal stress on the Mediterranean waters mainly through discharging different sources of pollutants through discharging different sources of pollutants through coastal waters [30]. The Egyptian Mediterranean coast has been influenced by untreated urban and industrial effluents that caused coastline degradation [44] and [45], particularly in Alexandria coast due to the high population growth and rapid development [45]. [46] reported $\mathrm{Zn}$ in gills of Mussels in France as $17.8+2.1 \mu \mathrm{g} / \mathrm{g}$. In the present study data the gills of $P$. radiata is considered less than that, as it is reported to be $13.33 \pm 0.2$ in El Asafra and $16.84 \pm 3.04 \mu \mathrm{g} / \mathrm{g}$ in the E.H.

In British Columbia, Canada along an apparent pollution gradient of acid mine drainage, tissue Zn concentrations were likely not high enough to have a direct impact on mussels (Mytilus edulis) health [47]. Metal binding induction differs markedly among the gills of the bivalve: mollusks Mytilus galloprovincialis and Ruditapes decussatus. [48] concluded that gills could preferentially be used in biomonitoring studies in the blue mussels. The gill tissue of Mytilus galloprovincialis is responsible for the uptake of metal ions from water [49]. Cd is not an essential element for animals [50]. He added that the occurrence of $\mathrm{Cd}$ in the marine environment was rare, therefore the impact of Cd on the environment was considerably small. [51] stated that cadmium was not needed for clams' growth and may be deleterious. Exposure to high levels of Cd does not stimulate Reactive Oxygen Species [52]. Gills are suggested as a possible route for accumulation of $\mathrm{Cd}$ as a possible route for Cd excretion [53]. [54] reported that Cd was present in the effluent and had accumulated significantly in mussels' gills. [55] reported that, the concentration of dissolved cadmium in gills of Pinctada radiata, collected from coastal zones was fluctuated between $3.03 \mu \mathrm{g} / \mathrm{g}$ wet weight and $0.57 \mu \mathrm{g} / \mathrm{g}$ wet weight. [46] reported; the level of Cd level in the gills of oysters collected from (Loire Atlantique, Bourgneuf, France) as $0.27+0.01 \mu \mathrm{g} / \mathrm{g}$ wet weight. They added; the level of Cd level in the gills of mussels collected from (Loire Atlantique, Bourgneuf, France), as $0.1+$ $0.01 \mu \mathrm{g} / \mathrm{g}$ wet weight.

An assessment of potential risks to human health due to consumption of the mussels (Mytilus edulis) and (Perna viridis) was undertaken for the metals. Metals could pose a health risk to heavy seafood consumers [56]. 
[54] reported; Cd accumulated significantly in mussels' gills. Uptake of metal in bivalves may take place at the gills and their relative importance is a function of the speciation of the metals in the environment [27]. The surveys of contaminants in shellfish conducted by Agency for Toxic Substances and Disease Registry [17] which reported the mean of Cd level for shellfish as $360 \mu \mathrm{g} / \mathrm{g}$ dry weight. [29] suggested that gill appeared to be more suitable organ for metal biomonitoring more than the hepatopancrease. [49] reported that the gill represented the quick answer of mussels to water concentrations of metals. [41] concluded; in nature metals in Pygananodon grandis are bound in the gills.

Very high Cd concentration may result from food chain bioaccumulation of elevated Cd levels brought into the productive surface water by upwelling into the region [40]. Lead is leader member of the toxic metals in the marine environment [50]. He added that metal variations were result of both natural and human activity. Moreover, some mollusk species represent a valuable seafood source. Therefore, high concentration of heavy metals in mollusk species gives dangerous indicator to deteriorate the marine life and pose a health risk to human. Exposure to $\mathrm{Pb}$ generally resulted in reduced oyster growth [11]. Reduction in growth has been reported to oyster Pinctada imbricata exposed to $270 \mu \mathrm{g} / \mathrm{l} \mathrm{Pb}$ [57]. Lead uptake at the gill surface may occur via a number of possible pathways including passive diffusion, active transport [11]. [51] stated that in an environment affected by contaminant oyster tissues have an opportunity to adsorb heavy metals. Surveys of contaminants in shellfish conducted by [17] found that the mean $\mathrm{Pb}$ concentration in health tissues of the shellfish should not exceed 250 $\mu \mathrm{g} / \mathrm{g}$, when $\mathrm{Pb}$ concentration exceeded $250 \mu \mathrm{g} / \mathrm{g}$, shellfish became harmful to consumers.

The bioavailability of metals such as lead concentrations in soft tissues of oysters Pinctada imbricata is highly dependent on the speciation or physicochemical forms of the metals in seawater [11]. Ruditapes philippinarium was exposed to different concentrations: $\mathrm{Pb}(350$ - $700 \mu \mathrm{g} / \mathrm{l})$ for seven days. The highest concentrations were found in the gills for $\mathrm{Pb}$ [28]. They reported that gills of clam Ruditapes philippinarum could be considered as an adequate target tissue for heavy metals. Some studies showed that both Mediterranean and red sea seawater are relatively unpolluted with heavy metals as compared to other regions in the world [25]. The selection of histology as indicator of disease and contamination was based on previous studies that showed strong relation between pollution and the histology of gills [12]. Histological examinations showed clearly different pathological changes in the structure of the gills of Pinctada radiata (Bivalve) exposed to pollution and collected from Alexandria coast, Egypt [55]. Some of these areas are polluted with different kinds of contaminants caused by the discharges of industrial and municipal effluents containing chemical and biological contaminants such as heavy metals [3]. Untreated sewage and waste waters were discharged annually from large numbers of outlets into Alexandria coastal area through local sewage system and endangers human health [6]. Marine bivalves have been used to monitor environmental health conditions and potential pollution by using the whole animal or specific organs to determine contamination levels and facilitate comparisons over space and time [5]. Several indicators of exposure to stress were reported in bivalves including, histopathological changes mostly confined to organs directly involved in the metabolism and detoxification of pollutants and elevated expression of stress proteins [58]. To protect public health, we have to harvest shellfish from approved waters where water quality standards have been met.

\section{References}

[1] Robertson, L.J. (2007) The Potential for Marine Bivalve Shellfish to Act as Out Breaks of Protozooan Infection in Human: A Review. International Journal of Microbiology, 120, 201-218. http://dx.doi.org/10.1016/j.ijfoodmicro.2007.07.058

[2] Madkour, H.A. (2005) Distribution and Relationships of Heavy Metals in the Gaint Clam (Tridacna maxima) and Associated Sediments from Different Sites in the Egyptian Red Sea Coast. Egyptian Journal of Aquatic Research, 31, 45-59.

[3] Abdel-Shafy, H.I. and Aly, R.O. (2002) Water Issue in Egypt: Resources, Pollution and Protection Endeavors. CEJOEM, 8, 3-21.

[4] Avelar, W.E.P., Mantelatto, F.L.M., Tomazelli, A.C., Silva, D.M.L., Shuhama, T. and Lopes, J.L.C. (2000) The Marine Mussel Perna perna (Mollusca, Bivalvia, Mytilidae) as an Indicator of Contamination by Heavy Metals in the Ubatuba Bay, Sao Paula, Brazil. Water, Air and Soil Pollution, 118, 65-72. http://dx.doi.org/10.1023/A:1005109801683

[5] Cöksu, M.Z.L., Akar, M., Cevic, F. and Findik, O. (2005) Bioaccumulation of Some Heavy Metals (Cd, Fe, Zn, Cu) in Two Bivalvia Species (Pinctada radiata Leach, 1814 and Brachidontespharaonis Fischer, 1870). Turkish Journal of 
Veterinary and Animal Sciences, 29, 89-93.

[6] Zyadah, M., Ibrahim, M. and Madkour, A. (2004) Impact of Environmental Parameters on Benthic Invertebrates and Zooplankton Biodiversity of the Eastern Region of Delta Coast at Damietta, Egypt. Egyptian Journal of Aquatic Biology and Fisheries, 8, 37-52.

[7] Chase, M.E., Jones, S.H., Hennigar, P., Sowles, J., Harding, G.C.H., Fereeman, K., Wells, P.G., Krahforst, C., Coombs, K., Crawford, R., Pederson, J. and Taylor, D. (2001) Gulpwatch: Monitoring Spatial and Temporal Patterns of Trace Metal and Organic Contaminats in the Gulf of Maine (1991-1997) with the Blue Mussel, Mytilus edulis L. Marine Pollution Bulletin, 42, 491-505. http://dx.doi.org/10.1016/S0025-326X(00)00193-4

[8] Kremling, K. (1983) The Behavior of Zn, Cd, Ni, Co, Fe, and Mn in Anoxic Baltic Waters. Marine Chemistry, 13, 87-108. http://dx.doi.org/10.1016/0304-4203(83)90019-1

[9] Lionetto, M.G., Giordano, M.E., Caricato, R., Pascariello, M.F., Marinosci, L. and Schettino, T. (2001) Biomonitoring of Heavy Metal Contamination along the Salento Coast (Italy) by Metallothionein Evaluation in Mytilus galloprovincialis and Mullus barbatus. Aquatic Conservation, 11, 305-310. http://dx.doi.org/10.1002/aqc.458

[10] O’Connor, T.P. (2002) National Distribution of Chemical Concentrations in Mussels and Oysters in the U.S.A. Marine Environmental Research, 53, 117-143. http://dx.doi.org/10.1016/S0141-1136(01)00116-7

[11] MacFarlane, G.R., Markich, S.J., Linz, K., Giffords, S., Dustan, R.H., O’Conner, W. and Russell, R.A. (2005) The Akoya Pearl Oyster Shell as an Archival Monitor of Lead Exposure. Environmental Pollution, 143, 166-173. http://dx.doi.org/10.1016/j.envpol.2005.10.042

[12] Sokolova, I.M., Evans, S. and Hughes, F.M. (2004) Cadmium-Induced Apoptosis in Oyster Haemocytes Involves Disturbance of Cellular Energy Balance but No Mitochondrial Permeability Transition. The Journal of Experimental Biology, 207, 3369-3380. http://dx.doi.org/10.1242/jeb.01152

[13] Graczyk, T.K., Conn, D., Marcoliese, D., Graczyk, H. and De Lafontaine, Y. (2002) Accumulation of Human Waterborne Parasites by Zebra Mussels (Dreissena polymorpha) and Asian Fresh Water Clams (Corbicula fluminea). Parasitology Research, 89, 107-112.

[14] Mariano, A., Lobardo, L., Florentino, C., Orlandella, B., Monticelli, L., Nostro, A. and Alonzo, V. (2005) Uptake of Escherichia coli, Vibrio cholerea Non-01 and Enterococcus durans and Depuration of Mussels (Mytilus galloprovincialis). International Journal of Food Microbiology, 99, 281-286.

[15] Stentiford, G.D., Longshow, M., Lyons, B., Tonesa, G., Green, M. and Feist, S.W. (2003) Histopathological Biomarkers in Estuarine Fish Species for the Assessment of Biological Effects of Contaminants. Marine Environmental Research, 55, 137-159. http://dx.doi.org/10.1016/S0141-1136(02)00212-X

[16] El Shenawy, N.S., Greenwood, R. and Abdel-Nabi, I.M. (2007) Histopathological Responses of Marine Mussel, Mytilus edulis to Long Term Exposure to Sublethal Level of Lindane and Alrazine. Acta Zoologica Sinica, 53, 899-909.

[17] Agency for Toxic Substances and Disease Registry (ATSDR) (2003) For Fish and Shell-Fish Evaluation for (Isla) de vieqmes Bombiong Range Public Health Assessment (PHA).

[18] Bigas, M., Sagrista, E., Gràcia, M., Durfort, M. and Poquet, M. (2000) Occurrence of Heavy Metals and Protozoan Parasites in the Mussel, Mytilus galloprovincialis, Collected in the Western Mediterranean. Exotoxicology and Environmental Reslorotion, 3.

[19] Peng, R., Tang, B., Zeng, Z., Yang, X. and Zhang, Z. (2001) Direct Determination of Pb, Zn and Cd in Environmental and Biological Samples by FAAS. Spectroscopy and Spectral Analysis, 21, 77-80.

[20] Rebelo, M.F., Amaral, M.C.R. and Pfeiffer, W.C. (2003) High Zn and Cd Accumulation in the Oyster Crassostrea rhizophorae and Its Relevance as a Sentinel Species. Marine Pollution Bulletin, 46, 1354-1358. http://dx.doi.org/10.1016/S0025-326X(03)00244-3

[21] Segninide Bravo, M.I. (2003) Influence of Salinity on the Physiological Conditions in Mussels, Pernaperna and Pernaviridis (Bivalvia: Mytilidae). Revista de Biologia Tropical, 51, 153-158.

[22] Nessim, R.B., Masoud, M.S. and Maximous, N. (2005) Water Characteristics of Alexandria Hot Spots. Egyptian Journal of Aquatic Research, 31, 25-37.

[23] Lalitha, K.V. and Surendran, P.K. (2005) Bacterial Profile of Black Clam (Villorita cyprinoids var, Cochinsis) and Clam Harvesting Waters from Vembanad Lake in Kerala (India). Fishery Technology, 42, 183-190.

[24] Zyadah, M. and Serag, M. (2001) Biodiversity and Management in Western Section of El-Salam Canal. Journal of Union of Arab Biologists, 16, 411-426.

[25] El Sikaily, A., Khaled, A. and El-Nemr, A. (2003) Heavy Metals Monitoring Using Bivalves from Mediterranean Sea and Red Sea. Environmental Monitoring \& Assessment, 98, 41.

[26] Shakweer, L.M., Shiridah, M., Fahmi, M. and El Fatah, A. (2006) Distribution and Concentrations of Trace Elements along the Mediterranean Coastal Water of Egypt. Egyptian Journal of Aquatic Research, 32, 95-127. 
[27] Otchere, F.A. (2003) Heavy Metals Concentrations and Burden in the Bivalves (Anadara senilia) Senilis, Crassostrea tulipa and Perna perna) from Lagoons in Ghana: Model to Describe Mechanism of Accumulation/Excretion. African Journal of Biotechnology, 2, 280-287.

[28] Blasco, J. and Puppo, J. (2005) Effect of Heavy Metals (Cu, Cd and Pb) on Aspartate and Alanine Aminotransferase in Ruditapes philippinarum (Mollusca: Bivalvia). Comparative Biochemistry and Physiology Part C, Pharmacology, Toxicology and Endocrinology, 122, 253-263.

[29] Soazig, L. and Marc, L. (2003) Potential Use of the Levels of the mRNA of a Specific Metallothionein Isoform (MT-20) in Mussel (Mytilus edulis) as a Biomarker of Cadmium Concentration. Marine Pollution Bulletin, 46, 1450 1455. http://dx.doi.org/10.1016/S0025-326X(03)00283-2

[30] Geffard, O., Budzinski, H. and His, E. (2004) The Effects of Elutriates from PAH and Heavy Metal Polluted Sediments on Crassostrea gigas (Thunberg) Embryogenesis, Larval Growth and Bio-Accumulation by the Larvae of Pollutants from Sedimentary Origin. Ecotoxicology, 11, 403-416. http://dx.doi.org/10.1023/A:1021024415695

[31] Rajalakshmi, S. and Mohandas, A. (2005) Copper-Induced Changes in Tissue Enzymes Activity in a Freshwater Mussel. Ecotoxicology and Environmental Safety, 62, 140-143. http://dx.doi.org/10.1016/j.ecoenv.2005.01.003

[32] Jing, G., Li, Y., Xie, L. and Zhang, R. (2006) Metal Accumulation and Enzyme Activities in Gills and Digestive Gland of Pearl Oyster (Pinctada fucata) Exposed to Copper. Comparative Biochemistry and Physiology Part C: Toxicology \& Pharmacology, 144, 184-190.

[33] Marigomez, I., Solo, M., Cajaraville, M.P., Angulo, E. and Giamberini, L. (2002) Celluar and Subcellular Distribution of Metal in Mollusks. Microscopy Research and Technique, 56, 358-392. http://dx.doi.org/10.1002/jemt.10040

[34] Au, D.W. (2004) The Application of Histo-Cytopathological Biomarker in Marine Pollution Monitoring. Marine Pollution Bulletin, 48, 817-834. http://dx.doi.org/10.1016/j.marpolbul.2004.02.032

[35] Abdel Nabi, I.M., ElShenawy, N.S., Taha, I.A. and Moawad, T.I. (2007) Oxidative Stress Biomarkers and Bioconcentration of Reldan and Roubdup by Edible Clam Ruditapes decussatus. Acta Zoologica Sinica, 53, 910-920.

[36] El Shenawy, N.S., Moawd, T.J.S., Mohallal, M.E., Abdel-Nabi, I.M. and Taha, I.A. (2009) Histopathologic Biomarker Response of Clam, Ruditapes decussatus, to Organ Phosphorous Pesticides Reldan and Roundup: Laboratory Study. Ocean Science Journal, 44, 27-34. http://dx.doi.org/10.1007/s12601-009-0004-5

[37] Choi, H.J., Ahn, I.Y., Lee, Y., Kim, K.W. and Jeong, K. (2003) Histological Responses of the Antarctic Bivalve Lalemula elliptica to a Short-Term Subleathal Level Cd Exposure. Ocean and Polar Research, 25, 147-154. http://dx.doi.org/10.4217/OPR.2003.25.2.147

[38] Waterman, B.T., Herlyn, M., Daehne, B., Bergmann, S., Meemken, M. and Kolodzey, H. (2008) Pathology and Mass Mortality of Pacific Oyster, Crassostrea gigas (Thunberg), in 2005 at the East Frisan Coast, Germany. Journal of Fish Diseases, 31, 621-630. http://dx.doi.org/10.1111/j.1365-2761.2008.00953.x

[39] Bebianno, M.J., Company, F., Serafim, A., Camus, L., Cosson, R.P. and Fiala-Médoni, A. (2005) Antioxidant Systems and Lipid Peroxidation in Bathymodiolus azoricus from Mid-Atlantic Ridge Hydrothermal Vent Fields. Aquatic Toxicology, 75, 354-373.

[40] Tomazelli, A.C., Martinelli, L.A., Avelar, W.E.P., de Camargo, P.B., Fostier, A.H., Ferraz, E.S.B., Krug, F.J. and Junior, D.S. (2003) Biomonitoring of $\mathrm{Pb}$ and $\mathrm{Cd}$ in Two Impacted Watersheds in Southeast Brazil Using the Freshwater Mussel Anodontites trapesialis (Lamarck, 1819) (Bivalvia: Mycetopodidae) as a Biological Monitor. Brazilian Archives of Biology and Technology, 46, 673-684. http://dx.doi.org/10.1590/S1516-89132003000400022

[41] Bonneris, E., Giguere, A., Perceval, O., Buronfosse, T., Masson, S., Hare, L. and Campbell, P.G. (2005) Role of Calcium Concretions in Metal Sequestration: Bivalve, Pyganodon grandis.

[42] El Gendy, A.H., Adham, Kh. and Ibrahim, H.M. (2003) Biomarkers of Pollution in the Clam, Scapharca inaequivalvis (Bruguiere, 1789). PH.D. Thesis, Alexandria University, Alexandria.

[43] EEA (European Environment Agency) (1999) State and Pressures of the Marine and Coastal Mediterranean Environment, Summary. EEA, Copenhagen.

[44] NDA Egypt (National Diagnostic Analysis) Egypt (2003) UNEP/MAP, 48.

[45] EEA (European Environment Agency) (2005) Priority Issues in the Mediterranean Environment. EEA Report No 5/2005, Copenhagen.

[46] Geret, F., Jouan, A., Turpin, V., Bebianno, M.J. and Cosson, R.P. (2002) Influence of Metal Exposure on Metallothionein Synthesis and Lipid Peroxidation in Two Bivalve Molluscs: The Oyster (Crassostrea gigas ) and Mussel (Mytilus edulis). Aquatic Living Resources, 15, 61-66. http://dx.doi.org/10.1016/S0990-7440(01)01147-0

[47] Grout, J.A. and Levings, C.D. (2001) Effects of Acid Mine Drainage from an Abandoned Copper Mine, Brilannia Mines, Howe Sound, British Columbia, Canada, on Transplanted Blue Mussels (Mytilus edulis). Marine Environmental Research, 51, 265-288. http://dx.doi.org/10.1016/S0141-1136(00)00104-5 
[48] Manduzio, H., Monsinjon, T., Galap, C., Leboulenger, F. and Rocher, B. (2004) Seasonal Variations in Antioxidant Defences in Blue Mussels Mytilus edulis Collected from a Polluted Area: Major Contributions in Gills of an Inducible Isoform of Cu/Zn-Superoxide Dismutase and of Glutathione S-Transferase. Aquatic Toxicology, 70, 83-93.

[49] Znidaric, M.T., Falnoga, I., Skreblin, M. and Turk, V. (2005) Induction of Metallothionein-Like Proteins by Mercury and Distribution of Mercury and Selenium in the Cells of Hepatopancreas and Gill Tissues in Mussel Mytilus galloprovincialis. Biological Trace Element Research, 111, 120-140.

[50] Madkour, H.A. (2005) Distribution and Relationships of Heavy Metals in the Gaint Clam (Tridacna maxima) and Associated Sediments from Different Sites in the Egyptian Red Sea Coast. Egyptian Journal of Aquatic Research, 31, 45-59.

[51] Huanxin, W., Lejum, Z. and Presley, B.J. (2000) Bioaccumulation of Heavy Metals in Oysters (Crassostrea virginica) Tissue and Shell. Environmental Geology, 39, 1216-1226. http://dx.doi.org/10.1007/s002540000110

[52] English, T.E. and Storey, K.B. (2003) Freezing and Anoxia Stresses Induce Expression of Metallothionein in the Foot Muscle and Hepatopancreas of the Marine Gastropod Littorina littorea. Journal of Experimental Biology, 206, 25172524. http://dx.doi.org/10.1242/jeb.00465

[53] Galay Burgos, M. and Rainbow, P.S. (2001) Availability of Cadmium and Zinc from Sewage Sludge to the Flounder, Platichthys flesus, via a Marine Food Chain. Marine Environmental Research, 51, 417-439. http://dx.doi.org/10.1016/S0141-1136(00)00249-X

[54] Gagné, F., Blaise, C., Aoyama, I., Luo, R., Gagnon, C., Couillard, Y., Campbell, P. and Slazar, M. (2002) Biomarker Study of a Municipal Effluent Dispersion Plume in Two Species of Freshwater Mussels. Environmental Toxicology, 17, 149-159. http://dx.doi.org/10.1002/tox.10046

[55] Radwan, E.H. (2009) Impact of Marine Pollution on Bivalve Pinctada radiata (Leach, 1814). Ph.D. Thesis, Alexandria University, Alexandria.

[56] Fung, C.N., Lam, J.C., Zheng, G.J., Connel, D.W., Monirith, I., Tanabe, S., Richardson, B.J. and Lam, P.K. (2004) Mussel-Based Monitoring of Trace Metal and Organic Contaminants along the East Coast of China Using Perna viridis and Mytilus edulis. Environmental Pollution, 127, 203-216. http://dx.doi.org/10.1016/j.envpol.2003.08.007

[57] De-Mora, S., Fowler, S.W., Wyse, E. and Azemard, S. (2004) Distribution of Heavy Metals in Marine Bivalves, Fish and Coastal Sediments in the Gulf and Gulf of Oman. Marine Pollution Bulletin, 49, 410-424. http://dx.doi.org/10.1016/j.marpolbul.2004.02.029

[58] Gifford, S., MacFarlane, G.R., O’Connor, W. and Dunstan, R.H. (2006) Effect of the Pollutants Lead, Zinc, Hexadecane and Octocosane on Total and Shell Growth in the Akoya Pearl Oyster, Pinctada imbricata. Journal of Shellfish Research, 25, 159-165. http://dx.doi.org/10.2983/0730-8000(2006)25[159:EOTPLZ]2.0.CO;2 